\title{
The Impact of the Global Commodity and Financial Crises on Poverty in Vietnam
}

\author{
James Thurlow ${ }^{1,2}$, Finn Tarp ${ }^{1}$, \\ Simon $\mathrm{McCoy}^{3}$, Nguyen Manh $\mathrm{Hai}^{4}$, \\ Clemens Breisinger ${ }^{2}$, and \\ Channing Arndt ${ }^{3}$
}

September 2010

\begin{abstract}
Economic growth in Vietnam has been fairly resilient to the global commodity and financial crises, but it is unclear why. In addition, the impact of the crises on employment and poverty is in dispute. We develop a dynamic computable general equilibrium model to decompose impacts and estimate distributional outcomes. Our results indicate that the 2008 commodity crisis increased employment and reduced poverty by favouring labour-intensive exports, especially in agriculture. The 2009 financial crisis reversed these gains. It pushed more than a million workers into unemployment and about 3 million people below the US\$2-a-day poverty line, with the vast majority of these being rural dwellers. The net effect of the crises left Vietnam ...

Keywords: economic crisis, growth, poverty, Vietnam

JEL classification: D5, G01, I38, O24

\section{Copyright @ UNU-WIDER 2010}

${ }^{1}$ UNU-WIDER, Helsinki; ${ }^{2}$ International Food Policy Research Institute, Washington DC; ${ }^{3}$ Department of Economics, University of Copenhagen; ${ }^{4}$ Central Institute of Economic Management, Hanoi (thurlow@wider.unu.edu; tarp@wider.unu.edu; simon.mccoy@econ.ku.dk; nmhai@mpi.gov.vn; c.breisinger@cgiar.org; channingarndt@gmail.com).

This study has been prepared within the UNU-WIDER project on New Directions in Development Economics.

UNU-WIDER acknowledges the financial contributions to the research programme by the governments of Denmark (Royal Ministry of Foreign Affairs), Finland (Ministry for Foreign Affairs), Sweden (Swedish International Development Cooperation Agency_Sida) and the United Kingdom (Department for International Development).
\end{abstract}


little changed from a baseline (no crises) path in terms of aggregate indicators including the poverty rate. An effective stimulus package has the potential to offset one third of the increase in poverty caused by the financial crisis leaving poverty rates below the (no crises) baseline.

\section{Acknowledgements}

We are grateful for useful comments from Xinshen Diao and Samuel Morley.

The World Institute for Development Economics Research (WIDER) was established by the United Nations University (UNU) as its first research and training centre and started work in Helsinki, Finland in 1985. The Institute undertakes applied research and policy analysis on structural changes affecting the developing and transitional economies, provides a forum for the advocacy of policies leading to robust, equitable and environmentally sustainable growth, and promotes capacity strengthening and training in the field of economic and social policy making. Work is carried out by staff researchers and visiting scholars in Helsinki and through networks of collabourating scholars and institutions around the world.

www.wider.unu.edu publications@wider.unu.edu

UNU World Institute for Development Economics Research (UNU-WIDER)

Katajanokanlaituri 6 B, 00160 Helsinki, Finland

Typescript prepared by Lorraine Telfer-Taivainen at UNU-WIDER

The views expressed in this publication are those of the author(s). Publication does not imply endorsement by the Institute or the United Nations University, nor by the programme/project sponsors, of any of the views expressed. 


\section{Introduction}

Vietnam's economy has grown rapidly over the last two decades, and poverty has declined without a significant deterioration in inequality (Glewwe et al. 2002; GSO 2007). Agriculture played a key role in this process. Large parts of the sector were transformed from subsistence to export-orientation and Vietnam became a major exporter of grains and other foods. During the 2008 commodity crisis, world prices for Vietnam's major exports rose rapidly, but during the 2009 financial crisis and subsequent global recession there was a sharp decline in world prices, demand for exports, and foreign investment. Economic growth in Vietnam slowed in early 2009, but the economy continued to expand and there were clear signs of recovery during the second half of the year. This suggests that, from a macroeconomic perspective, Vietnam has so far weathered the two crises fairly well.

It is uncertain, however, what the effect of the crises has been on workers and households and what the lasting welfare implications will be. Industrial workers were laid off in early 2009, possibly resulting in migration back to rural areas (Van 2009), but it is unclear to what extent agriculture and the rural non-farm economy cushioned the incomes of displaced workers and their households. Moreover, Vietnam's government responded to the financial crisis by introducing a stimulus package aimed at stabilizing capital markets, encouraging domestic investment and extending social security. The extent to which these measures might offset growth and welfare losses is the subject of debate.

Given the uncertainty surrounding household-level outcomes, we estimate the impact of the commodity and financial crises on growth, employment, and poverty. We also assess the government's stimulus package. Section 2 describes Vietnam's economy and its growth performance during the crises. Section 3 considers the impact channels through which economic growth may have been affected. To translate macro-level impacts into household incomes and poverty we develop a dynamic computable general equilibrium (DCGE) model described in Section 4. Section 5 discusses the simulations and results, and the final section concludes.

\section{Vietnam's economic performance during the crises}

\subsection{Structure of the Vietnamese economy}

Total gross domestic product (GDP) was US\$61.3 billion in 2007, equivalent to US\$743 per capita for Vietnam's 82.5 million people. ${ }^{1}$ Industry generates two-fifths of total GDP and one-fifth of employment, two-thirds of which is in manufacturing (Table 1). Industrial goods also generate a major share of Vietnam's export earnings due to large contributions from textile and clothing (25.8 per cent), agro-processing (12.5 per cent), and metals and machinery (11.9 per cent). Oil has also contributed significantly (19.0 per cent). Vietnam is equally dependent on industrial imports, particularly metals and machinery (38.5 per cent), fuel and chemicals (22.5 per cent), and textiles (15.3 per cent).

1 Adjusting for purchasing power, per capita GDP in 2006 was US\$2,363 (World Bank 2009a). 
Table 1: Structure of the Vietnamese economy, 2007

\begin{tabular}{|c|c|c|c|c|c|c|}
\hline & \multicolumn{4}{|c|}{ Share of total (\%) } & \multirow{2}{*}{$\begin{array}{c}\text { Export } \\
\text { intensity }\end{array}$} & \multirow{2}{*}{$\begin{array}{l}\text { Import } \\
\text { intensity }\end{array}$} \\
\hline & GDP & Employment & Exports & Imports & & \\
\hline Total GDP & 100.0 & 100.0 & 100.0 & 100.0 & 32.4 & 39.1 \\
\hline Agriculture & 22.1 & 53.9 & 7.6 & 2.0 & 21.3 & 8.4 \\
\hline Crops & 13.4 & 36.6 & 4.6 & 1.4 & 23.3 & 10.3 \\
\hline Livestock & 2.7 & 8.5 & 0.4 & 0.0 & 7.4 & 1.6 \\
\hline Forestry/fishing & 5.9 & 8.8 & 2.6 & 0.6 & 23.4 & 8.2 \\
\hline Industry & 41.7 & 19.9 & 76.1 & 85.4 & 38.5 & 48.7 \\
\hline Mining & 10.9 & 0.9 & 19.0 & 0.6 & 82.9 & 14.9 \\
\hline Manufacturing & 20.1 & 13.3 & 57.1 & 84.9 & 40.7 & 57.8 \\
\hline Agro-processing & 5.8 & 4.1 & 12.5 & 4.3 & 33.5 & 20.3 \\
\hline Textiles/clothing & 3.7 & 2.2 & 25.8 & 15.3 & 68.6 & 62.2 \\
\hline Wood/paper & 1.4 & 0.8 & 2.9 & 3.0 & 34.9 & 44.2 \\
\hline Fuel/chemicals & 2.8 & 2.3 & 3.2 & 22.5 & 21.8 & 74.7 \\
\hline Metals/machinery & 4.4 & 3.0 & 11.9 & 38.5 & 36.8 & 70.4 \\
\hline Other & 2.8 & 1.4 & 1.4 & 2.7 & 8.1 & 17.6 \\
\hline Other & 10.7 & 5.7 & 0.0 & 0.0 & 0.0 & 0.0 \\
\hline Services & 36.2 & 26.1 & 16.3 & 12.6 & 22.0 & 20.5 \\
\hline
\end{tabular}

Note: GDP is gross domestic product; 'export intensity' is the share of exports in gross domestic output; 'import intensity' is the share of imports in total demand.

Source: Authors' calculations using the 2007 social accounting matrix (Arndt et al. 2009).

Agriculture is another key sector, generating one-fifth of total GDP and employing half the country's workforce. Crops dominate, with paddy rice alone accounting for 6.8 per cent of total GDP. Seafood and traditional crops, such as rubber and coffee, have strong downstream linkages to manufacturing, where raw agricultural products are processed and often exported. Agriculture in Vietnam is more export-oriented than in most developing countries, with agriculture and agro-processing together generating one-fifth of all export earnings. Moreover, 10 per cent of agricultural investment is FDI (GSO 2009a). Agriculture in Vietnam thus has relatively strong ties to global market conditions.

Agriculture's importance extends beyond its contribution to GDP, employment and export earnings. Three quarters of Vietnam's population live in rural areas, where most derive some farm income. Poverty is also much higher in rural areas. According to the 2006 Vietnam Household Living Standard Survey (VHLSS), 47 per cent of Vietnam's population lives below the US\$2-a-day poverty line (GSO 2007). Yet equivalent rural and urban poverty rates are 59 per cent and 15 per cent respectively, implying that about 90 per cent of the poor population is in rural areas. Moreover, poorer urban households spend half of their incomes on food. Agriculture therefore plays a crucial role in households' livelihoods, especially for the poor.

\subsection{Economic growth during the crises}

Vietnam's real economy expanded at an average 7.5 per cent per year during 2000-07 (Figure 1). Growth in total GDP decelerated slightly during the 2008 commodity crisis driven 
by a small slowdown in services and a larger decline in industry. Falling industrial growth was due to construction, whose annualized growth rate dropped from 12 per cent to 0 per cent. Agricultural growth, by contrast, rose from 3 per cent to 4 per cent due to expanded crop and aquaculture production (GSO 2009b). Vietnam's overall performance during the 2008 commodity crisis was thus characterized by stronger agricultural growth and continued industrial growth outside of construction.

Figure 1: Annualized economic growth by major sectors, 2000-09

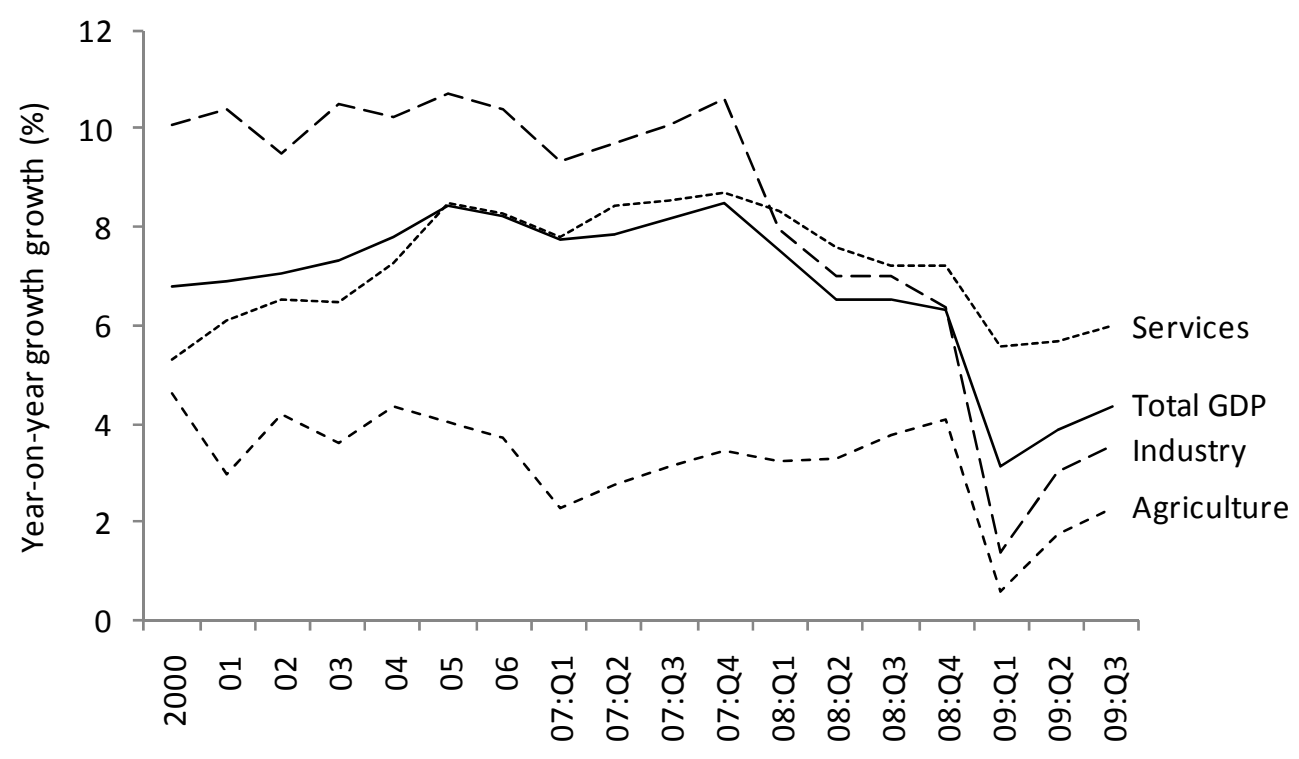

Source: Authors' calculations using General Statistical Office (GSO 2009a, 2009b).

Economic growth slowed sharply in the first quarter of 2009, which marks the height of the financial crisis and the onset of the global recession. Industry's deceleration was almost exclusively due to manufacturing, with firms temporarily closing factories and dismissing workers (Van 2009). The financial crisis also marked a reversal for agriculture. Crop production growth slowed from 5.7 per cent during the first half of 2008 to 0.7 per cent in 2009 (GSO 2009b). The decline was even more pronounced for aquaculture, whose annualized growth rate fell from 30 per cent to 2 per cent. Although rice and seafood were affected by lower export demand, at least some of their poor performance in early 2009 was due to adverse weather conditions. The slight slowdown in services resulted from weakened foreign tourism. ${ }^{2}$ Ultimately, only transport and construction grew robustly during the 2009 financial crisis with all other sectors either stagnating or contracting. However, during the second half of 2009 agriculture and industry have shown signs of recovery, suggesting that the negative growth effects of the financial crisis may be fairly short-lived.

\section{Growth and poverty impact channels}

This section examines the apparent resilience of national GDP growth to the two crises, considering various impact channels, including the financial sector; foreign direct investment; world prices and trade; and the government's stimulus package. We also identify various channels linking the macro-level impacts of the crises to household incomes and poverty.

2 The number of tourists visiting Vietnam fell by 20 per cent in 2009 from 2 million in 2008 (GSO 2009b). 


\subsection{Financial sector and monetary policy}

Vietnam's financial sector has been fairly insulated from the financial crisis. Andersen et al. (2008) identify three sources of potential financial instability in developing countries resulting from the financial crisis: (i) exposure to illiquid/downgraded assets in developed countries; (ii) presence of foreign-owned domestic banks; and (iii) liquidity constraints from a shortage of short-term capital in international money markets. None of these have been present in Vietnam.

First, the country has limited direct exposure to the 'toxic assets' that undermined many Western financial institutions. Vietnam's banks are generally well capitalized with limited reliance on credit lines to Western banks (i.e., low balance sheet exposure). Nevertheless, asset prices, and in particular stocks, are highly sensitive to market sentiment and the external environment. The stock-market therefore plummeted in late 2008 and early 2009.

Second, despite the rising market shares of joint-stock commercial banks, most banking assets remain on the balance sheets of five state-owned banks. This limited exposure to troubled foreign-owned banks and provided the government with a mechanism for controlling credit rates, which proved to be a key instrument in its stimulus package. The state-supported Vietnam Bank for Social Policy (VBSP) also provided a means of efficiently disbursing government-subsidized loans to rural communities.

Finally, the tightening of monetary policy in mid 2008 to cool the economy was reversed in late 2008 due to the financial crisis. Monetary policy remained loose, with government interest rate subsidies expanding credit and money supply during 2009. Overall, total liquidity (measured by M2) rose by 35 per cent in the first half of 2009. The supply of shortterm capital was therefore expanded and the impact of the crisis on the financial sector has remained small.

\subsection{Foreign direct investment}

One motivation for tightening monetary policy in 2008 was the high levels of inflation caused in part by large surges in FDI (Figure 2). The financial crisis caused a sharp contraction in global capital markets in late 2008, including foreign capital inflows to Vietnam. By early 2009, FDI had fallen below 2007 levels. This slowdown in investment helped stabilize consumer prices, with inflation returning to pre-2007 trends. Thus, a positive outcome of the financial crisis was that it cooled the overheating Vietnamese economy.

To isolate the effects of the financial crisis on FDI, we compare flows in late 2008 with those in late 2007, treating the spike in FDI in 2008 as independent of the two crises. This comparison suggests that almost all of the reduction in FDI caused by the financial crisis occurred in the industrial sectors, with manufacturing being the worst affected (GSO 2009b). FDI in agriculture and downstream agro-processing also declined, although these were among the least affected sectors. By contrast, FDI in the transport sector rose during the crisis, possibly explaining its continued growth while other sectors declined (Section 2). Using 2007 trends as a baseline and excluding the transport sector, FDI inflows to Vietnam were more than 20 per cent below what they would have been had the financial crisis not occurred. The decline in FDI has implications for growth in both contemporaneous and future periods. 


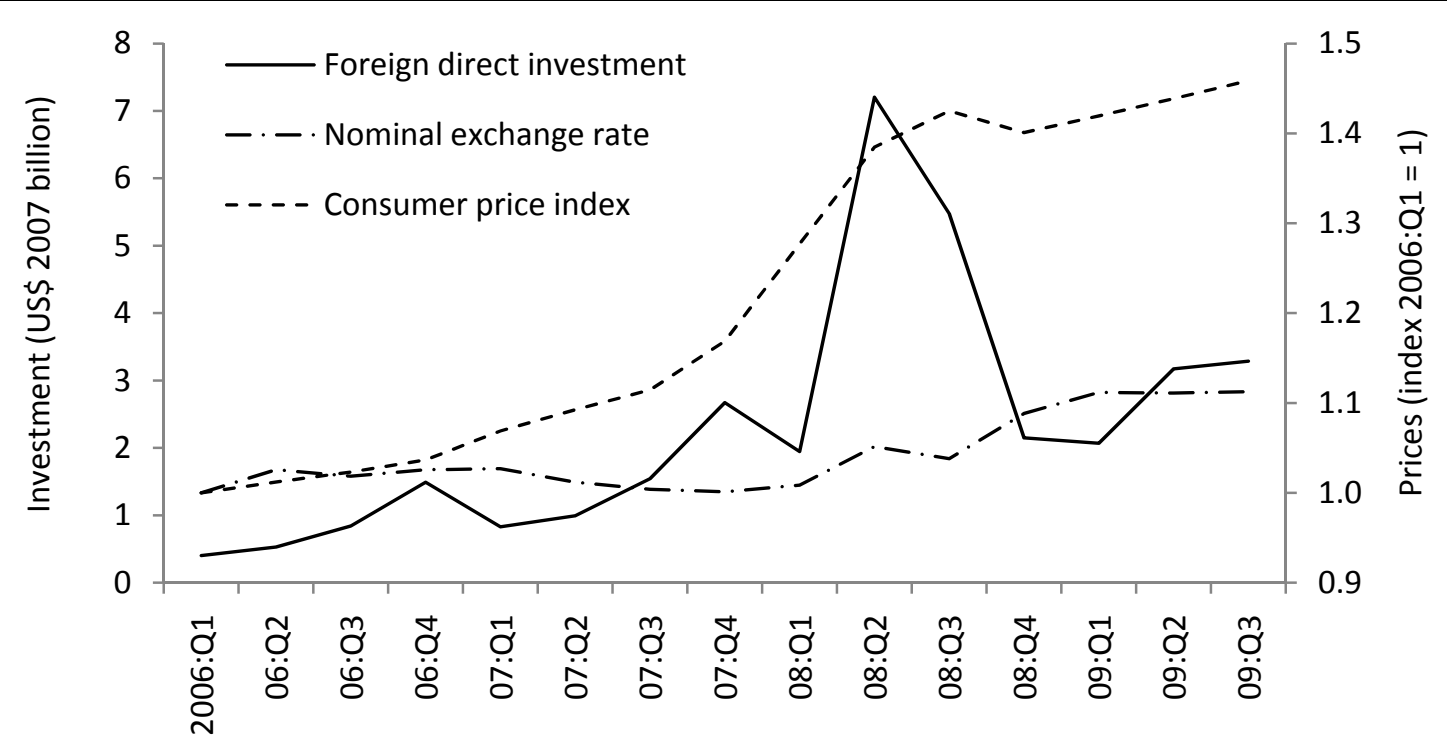

Note: Foreign direct investment is implemented and not registered investment.

Source: Authors' calculations using General Statistical Office (GSO 2009a, 2009b).

\subsection{World commodity prices and foreign trade}

World commodity prices rose rapidly in late 2007 and peaked in mid 2008 (Figure 3). Food and energy prices rose especially fast, with the largest increases recorded for rice and crude oil. Both of these commodities are major exports for Vietnam, generating a quarter of export earnings. Smaller price increases were recorded for major imports, such as metals and machinery. Overall, the 2008 commodity crisis improved Vietnam's terms of trade. However, rising prices generated worldwide concern for food security, and prompted Vietnam to ban incremental rice exports during the first half of 2008. In other words, planned exports were permitted to continue (and to reap the terms of trade gain). However, agents were prevented from increasing export levels thus preventing reallocation of domestic supplies to exports in response to higher world prices.

The financial crisis and subsequent global recession caused world prices to fall rapidly to levels similar to those of 2007. Crude oil prices initially declined below 2007 levels, thus having a detrimental effect on Vietnam's terms of trade, but prices had returned to 2007 levels by late 2009. Moreover, food prices remained similar to or even above 2007 levels throughout the financial crisis. By contrast, metals and minerals prices fell below 2007 levels and their rebound by late 2009 remained fairly modest. This suggests that Vietnam's import prices may have fallen by more than export prices during the financial crisis. It also underlines the divergent effects of the commodity and financial crises.

Changes in world prices reflect shifts in global demand. Vietnam is a very open economy and, as such, is vulnerable to falling export demand. Merchandise exports fell during the first quarter of 2009 relative to the quarterly average for 2008 (see Table 2). Most of this decline was driven by agriculture, food and textiles, where exports fell by about 40 per cent. Crude oil exports remained relatively stable, albeit below peak 2008 values. Moreover, some export sectors expanded during the crisis, most notably high-value minerals. Ultimately, while the 
value of most export products declined during the financial crisis, by mid 2009 they had again surpassed 2007 levels. This may reflect price-inelastic demand for many of Vietnam's exported products, such as grains and low-value clothing.

Figure 3: World commodity prices, 2006-09

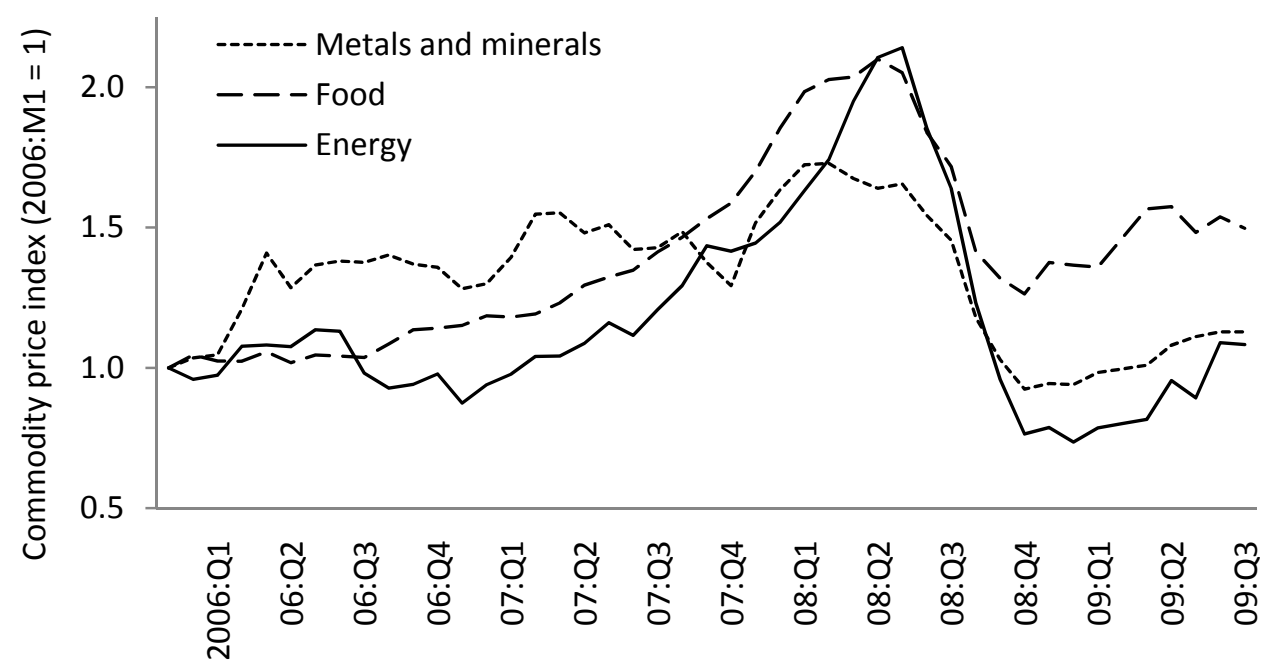

Source: Authors' calculations using World Bank (2009b).

Table 2: Foreign merchandise trade, 2006-09

\begin{tabular}{|c|c|c|c|c|c|c|}
\hline & \multicolumn{6}{|c|}{ Quarterly average value (constant 2007 US $\$$ million) } \\
\hline & 2006 & 2007 & 2008 & $\begin{array}{c}2009 \\
\text { Q1 }\end{array}$ & $\begin{array}{c}2009 \\
\text { Q2 }\end{array}$ & $\begin{array}{c}2009 \\
\text { Q3 }\end{array}$ \\
\hline Trade balance & -789 & $-3,082$ & $-1,357$ & 4,341 & -408 & -897 \\
\hline Imports & 10,943 & 15,191 & 18,472 & 10,643 & 16,104 & 16,648 \\
\hline Exports & 10,155 & 12,110 & 17,116 & 14,984 & 15,696 & 15,751 \\
\hline Agric/food & 2,134 & 2,121 & 2,843 & 1,585 & 2,093 & 1,627 \\
\hline Crude oil & 2,575 & 3,153 & 4,041 & 3,358 & 3,991 & 4,178 \\
\hline Textiles/clothing & 2,080 & 2,468 & 3,499 & 2,220 & 4,122 & 3,262 \\
\hline Other & 3,366 & 4,367 & 6,732 & 7,820 & 5,491 & 6,685 \\
\hline
\end{tabular}

Source: Authors' calculations using General Statistical Office (GSO 2009a, 2009b).

There were also substantial declines in import demand, which almost halved during the first quarter of 2009. This was driven by falling FDI, which is highly import-intensive and accounted for about 40 per cent of merchandise imports in 2008 (GSO 2009a). Lower inflation and some depreciation of the nominal exchange rate also helped reduce import demand (Figure 2). Ultimately, imports declined by more than exports pushing the trade balance into surplus in the first three months of 2009. This raised national GDP and offset declining foreign investment. The strong links between FDI and imports reduces the risks typically associated with current account deficits. While the decline in FDI clearly translated into reduced investment and hence reduced future growth, it also eliminated the current account deficit thus obviating the frequently experienced need to restructure the economy to produce more tradables and fewer non-tradables when a principal source of foreign exchange declines. This automatic stabilization mechanism explains some of the resilience of Vietnam's economic performance during the financial crisis. 


\subsection{Government stimulus package}

As in many countries, Vietnam's government put in place a stimulus package in early 2009 to bolster investment and private consumption during the financial crisis. The International Monetary Fund estimated that Vietnam’s proposed stimulus package was worth US\$4billion, although the official budget was US\$8.6million (Table 3). A large component of the stimulus package was a 4 per cent interest rate subsidy, which is estimated to have generated US\$24.1billion in additional lending. About 68 per cent of these subsidies went to private businesses and 17 per cent to households. The intended impact of the stimulus package was to offset some of the declines in foreign investment, and may explain the strong growth in construction from mid 2009 onwards.

Table 3: Vietnam's proposed stimulus package (January 2009)

\begin{tabular}{lc}
\hline & US\$ billion \\
\hline Total proposed cost & 8.6 \\
Interest support & 1.0 \\
Delayed payback for construction capital in 2009 & 0.2 \\
Advanced capital investment (from 2009/10) & 2.2 \\
Transfer planned investment capital (2008-09) & 1.8 \\
Additional government bonds & 1.2 \\
Tax reduction & 1.6 \\
Other expenditures (including social safety) & 0.6 \\
\hline
\end{tabular}

Source: Government of the National Assembly Report 77/CP-KTTH (5 May 2009).

The largest component of the stimulus package is 'advanced capital', which brings forward planned investments from future budgets. The government announced that half of the funds would be devoted to transport infrastructure and the rest would be divided evenly between agriculture and small businesses. It is unclear how much of these funds were actually disbursed, but the government announced in late 2009 that it would implement a US\$3.3billion stimulus package targeting agriculture and rural development. Most of these funds have been allocated to infrastructure, including irrigation, grain storage, and farm machinery. Finally, in its original stimulus package the government directly targeted households via tax relief and social transfers.

\subsection{Household consumption}

To date, no firm quantitative evidence exists which can gauge the effects of the crises on private consumption. However, there are a range of impact channels that should be considered. The first channel is via domestic prices. The effect of world price changes depends on the degree of price transmission and the composition of households' incomes and expenditures. Some empirical studies indicate that international to domestic price transmission is high in Vietnam (Rapsomanikis and Sarris 2007). This is potentially important for food products, which comprise 47 per cent and 33 per cent of rural and urban households' consumption baskets respectively (Arndt et al. 2009). Food is also a larger consumption item for low-income consumers, implying that changes in world food prices could have significant implications for poverty. However, households, especially the poor in rural areas, often produce their own food. Indeed, home production accounts for about a third of total consumption in Vietnam. World price impacts will be substantially smaller for those households that produce a large share of their own consumer goods, and the degree of price transmission remains subject to debate (Abbott et al. 2009). 
The second channel is via employment and wages. Although national GDP did not fall in 2008-2009, there were larger adjustments at the firm-level. Vietnam's government estimates that 80,000 jobs were lost in the early stages of the financial crisis and that the total job losses may be as high as 400,000 (cited in Van 2008). Many factories ceased production in early 2009 causing unemployment rates to rise. Moreover, the government suggests that a million workers were 'affected' by the crisis, meaning that workers who retained their jobs earn lower wages. Thus, the impact of the crisis on employment and wages depends on shifts in firms’ profitability and labour demand.

The final impact channel is taxes and transfers. Vietnamese households received US $\$ 3.5$ billion in foreign transfers in 2007. This was US\$44 per capita or 7.3 per cent of total household income. Projections indicate that remittances fell by 8 per cent in 2009 (World Bank 2009c). This may not directly affect poverty, however, since higher-income households receive most remittances. For instance, transfers from abroad generated 15 per cent of incomes for households in the top income quintile in 2007, but less than 2 per cent of incomes for the bottom three quintiles (Arndt et al. 2009). Moreover, some households will benefit from new social transfers in the government's stimulus package. Existing social transfers averaged US\$27 per capita in 2007 and were biased towards urban households in the middle of the income distribution.

In summary, this section has suggested why national GDP growth in Vietnam did not collapse during the two crises. The 2008 commodity crisis improved terms of trade, especially for agriculture, prior to policy intervention. Evidence also indicates that falling FDI during the 2009 financial crisis was associated with a dramatic decline in imports and was further offset by the government's stimulus package. Throughout the crisis, the financial sector remained insulated from disruptions in developed countries' financial systems. However, there is so far little quantitative evidence on the distributional impacts on private consumption or welfare effects on different population groups.

\section{Economy-wide modeling framework}

\subsection{A core general equilibrium model}

Table 4 presents the equations of a simple DCGE model illustrating how changes in world prices and foreign capital inflows affect employment and household incomes. Producers of each commodity $c$ produce a level of output $Q$ by employing the factors of production $F$ under constant returns to scale (exogenous productivity $\alpha$ ) and fixed production technologies (fixed factor input shares $\delta$ ) (eq. [1]). Profit maximization implies that factor payments $W$ are equal to average production revenues (eq. [2]). Total labour, land, and capital supply $s$ are fixed, implying full employment and intersector mobility (eq. [10]). This means that declining farm/factory production causes factor demand to fall, which in turn lowers economy-wide factor returns and affects production in other sectors. 
Table 4: Core model equations

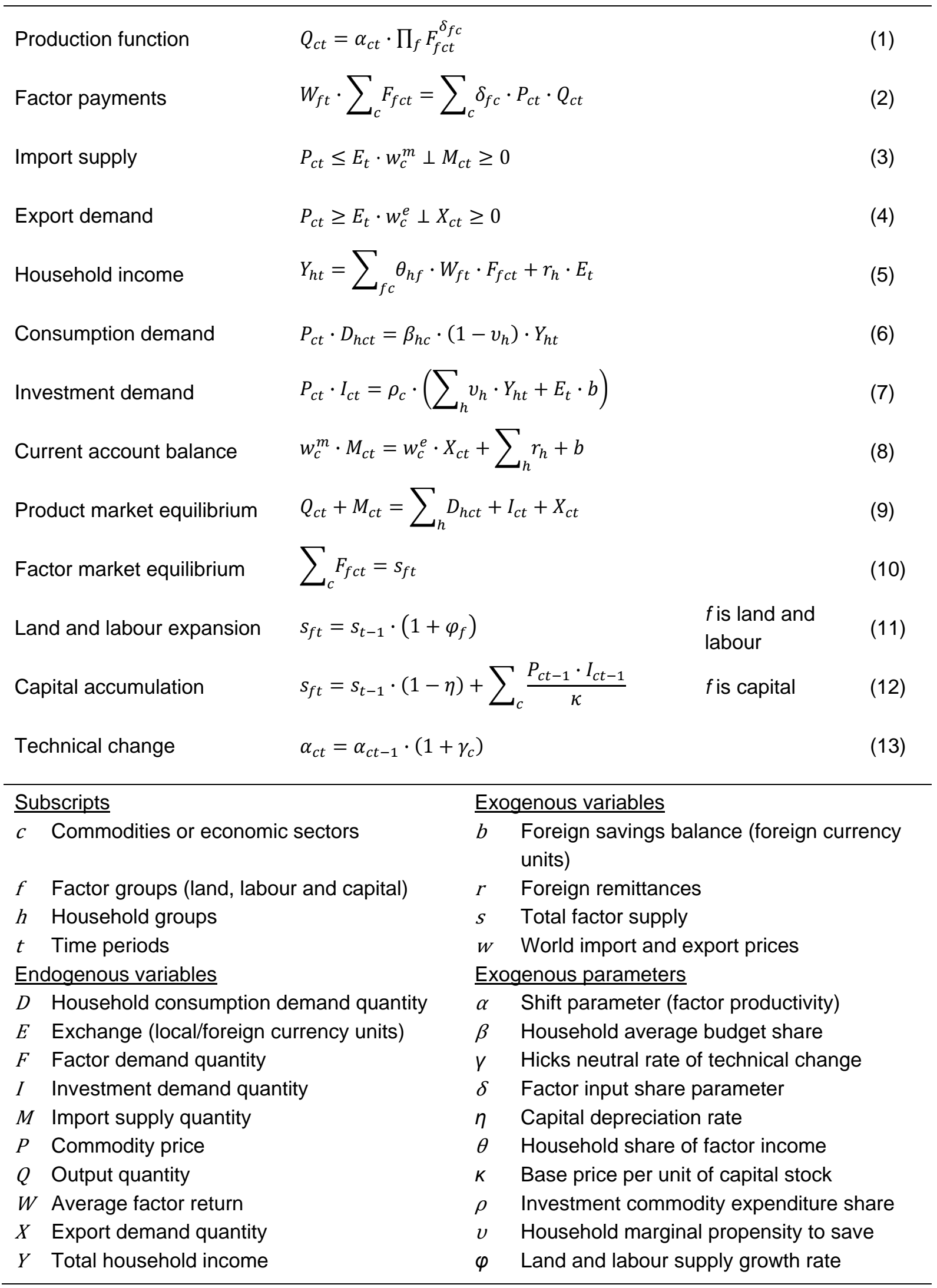

Source: Authors. 
Foreign trade is determined by comparing domestic and world prices, where the latter are fixed under a small country assumption. The simple model implements trade as a complementarity problem. If domestic prices exceed world import prices $w^{m}$ (adjusted by exchange rate $E$ ) then the quantity of imports $M$ increases (eq. [3]). Conversely, if domestic prices fall below world export prices $w^{e}$ then export demand $X$ increases (eq. [4]). To ensure macroeconomic consistency, a flexible real exchange rate adjusts to maintain a fixed current account balance $b$ (measured in foreign currency units) (eq. [8]). This means that falling world prices reduces exports and causes the real exchange rate to depreciate in order to enhance other export producers' competitiveness and reduce overall import demand. Similarly, reducing FDI inflows (i.e., lowering $b$ ) causes the real exchange rate to depreciate.

Factor incomes are distributed to households using fixed income shares $\theta$ based on households' initial factor endowments and are combined foreign remittances $r$ adjusted by the exchange rate (eq. [5]). Incomes $Y$ are then saved (based on marginal propensities to save $v$ ) or spent on consumption $C$ (according to marginal budget shares $\beta$ ) (eq. [6]). Household savings and foreign capital inflows are collected in a national savings pool from which investment demand $I$ is financed (i.e., a savings-driven investment closure) (eq. [7]). Finally, prices $P$ equilibrate product markets such that demand for each commodity equals supply (eq. [8]). The model therefore links production and trade to household incomes via changes in market prices, employment and factor returns.

The model's variables and parameters are calibrated to empirical data from a social accounting matrix that captures the initial structure of Vietnam's economy in 2007 (see Arndt et al. 2009). Parameters are then adjusted over time to reflect demographic and economic trends and the model is re-solved for a new equilibrium each half-year during 2007-11. Between periods the model is updated to reflect exogenous rates of land and labour expansion $\varphi$ (eq. [11]). The rate of capital accumulation is determined endogenously, with previous period investment converted into new capital stocks using a fixed capital price $\kappa$ (eq. [12]). This is added to previous capital stocks after applying a depreciation rate $\pi$. Finally, the model captures total factor productivity (TFP) through the production function's shift parameter $\alpha$, with the rate of technical change $\gamma$ determined exogenously.

\subsection{Extensions to the full Vietnam model}

The above model illustrates how production, trade and household incomes are linked in our analysis. However, the full model drops some of the core model's more restrictive assumptions (see Lofgren et al. 2002; Thurlow 2004). Constant elasticity of substitution production functions allow factor substitution based on relative factor prices (i.e., $\delta$ is no longer fixed). The model identifies 66 sectors (26 agriculture, 22 industry, and 10 services). Intermediate demand in each sector, which was excluded in the core model, is now determined by fixed technology coefficients (i.e., Leontief demand).

Based on VHLSS 2006, labour markets are segmented across rural/urban areas and four education groups: (1) below primary schooling; (2) completed primary; (3) completed secondary; and (4) tertiary. Agriculture-specific factors include crop land, livestock, and fisheries stocks. All workers have upward-sloping supply curves implying a binding reservation wage. 3 Agricultural factors are fully employed and earn flexible returns. Capital is immobile and new capital is allocated across sectors based on profit rate differentials under

3 Wage elasticities are set at 0.30 for lower-educated labour groups and 0.15 for higher-educated labour. This reflects greater underemployment in rural areas where education levels are lower. 
a 'putty-clay' specification. This means that once capital is invested it cannot be used for other purposes. When annual profit rates on fixed capital fall by more than 20 per cent we assume that capital utilization declines. Unused capital continues to depreciate but is reactivated once profit rates improve. This specification of capital underutilization permits temporary rises in unemployment during the crises while retaining the producers' capacity to expand production under better market conditions.

International trade is captured by allowing production and consumption to shift imperfectly between domestic and foreign markets, depending on the relative prices of imports, exports and domestic goods (inclusive of indirect taxes). This differs from the core model, which assumed perfect substitution between domestic and foreign goods (i.e., homogenous products). This extension captures differences in domestic and foreign products and allows for observed two-way trade. Vietnam is still considered a small economy (i.e., world prices are fixed). Vietnam's real exchange rate (i.e., price index of tradable-to-non-tradable goods) adjusts to maintain a constant current account balance. Production and trade elasticities are drawn from Dimaranan (2006).

Households maximize a Stone-Geary utility function so that a linear expenditure system determines consumption with non-unitary income elasticities. 4 Households are disaggregated across rural and urban areas and by per capita expenditure quintiles, giving a total of 10 representative households in the DCGE model. Households pay taxes to the government based on fixed direct and indirect tax rates. Tax revenues finance exogenous recurrent spending, resulting in an endogenous fiscal deficit. Finally, the analysis includes a separate microsimulation module. In the module, each respondent in VHLSS is linked to their corresponding representative household group in the DCGE model. Changes in commodity prices and households' consumption spending are passed down from the DCGE model to the microsimulation module. Total per capita consumption and poverty measures are then recalculated assuming Leontief preferences by individual households.

\section{Model simulations and results}

\subsection{Baseline scenario}

The DCGE model is initially calibrated to track observed trends in key demographic and macroeconomic indicators. Annual labour force growth of about 2.5 per cent is targeted during 2007-11 (World Bank 2009a). Higher-educated labour grows faster than other labour types reflecting improvements in human capital stocks. For example, based on recent surveys, the supply of workers with tertiary schooling expands at 6.5 per cent per year, while the supply of workers with only primary schooling grows at 2.3 per cent (GSO 2009b). Technical change is also biased towards higher-educated labour, and is consistent with the negligible deviations in relative wages observed since 2000.

Biased technical change favours skill-intensive sectors. Accordingly, total GDP growth of about 7.5 per cent per year in the baseline scenario is driven by industry and services, which grow at about 8.5 per cent during 2007-11. Agriculture grows at a slower 3 per cent per year. The national US\$2-a-day poverty headcount rate declines from 47.3 per cent in 2007 to 42.2 per cent by 2011. Although poverty declines in both rural and urban areas, slower agricultural

4 Income elasticities were estimated by Bingxin Yu (IFPRI) using the 2006 VHLSS. 
growth results in slightly smaller reductions for rural households. A comparison with observed trends for 2005-07 suggests that this baseline adequately captures Vietnam's growth path prior to the commodity and financial crises. The baseline scenario thus provides a reasonable counterfactual against which we can measure the impacts of the crises.

\subsection{Simulating the commodity and financial crises}

Section 3 identified impact channels linking the crises to economic growth. Here we describe the shocks imposed on the DCGE model. In the first simulation, we estimate the impact of the 2008 commodity crisis. Detailed world prices were taken from World Bank (2009b). The real price changes imposed on the model are shown in Table 5 for Vietnam's main traded commodities. In the commodity crisis scenario, we only impose the price changes that took place during 2008 (i.e., the first two columns) so this is referred to as the 'food/fuel' simulation.

Table 5: Shocks to the model

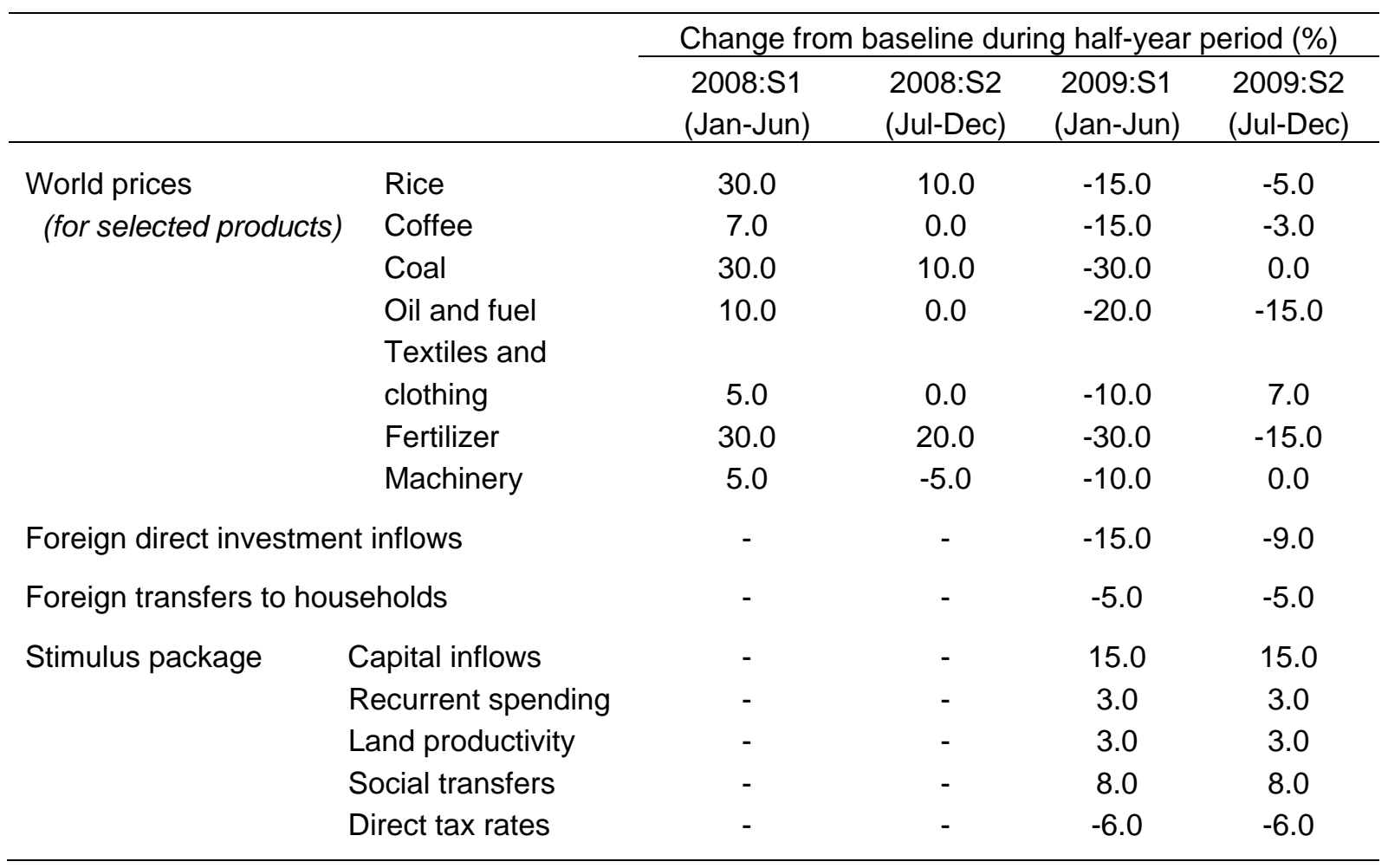

Source: Authors' calculations using world prices from World Bank (2009b).

In assessing the 2009 financial crisis, we take the results from the 'food/fuel' simulation as our starting point (e.g., end 2008). We then incrementally include the changes in world prices, foreign investment and foreign remittances. In addition, rates of productivity growth are changed in order to track the GDP and trade changes described in Table 2. Changes in world prices during 2009 are shown in the final two columns of Table 5. These are imposed on the model in the '2009 prices' simulation. In the 'FDI outflows' simulation we include both declining world prices and FDI flows. FDI falls by 15 per cent in the first and second halves of 2009, which is a cumulative decline of about 25 per cent for the year. Finally, in the 'remittances' simulation we reduce foreign transfers to households by about 10 per cent based on projections from World Bank (2009c). Absolute declines in transfers are distributed proportionally across rural/urban households according to remittance receipts reported in 
VHLSS. The 'remittances' scenario captures all three impact channels from Section 3 and thus reflects the overall impact of the 2009 financial crisis.

Finally, we simulate the government's stimulus package. First, interest support and advanced capital offset declining FDI by injecting foreign reserves into the private sector. These are modeled as a US $\$ 1.45$ billion increase in external funds transferred to the real economy. 5 Secondly, we simulate a 3 per cent or US\$300 million increase in recurrent government spending which raises agriculture's productivity by 6 per cent. 6 Third, we proportionally reduce direct tax rates on enterprises and households by about 12 per cent (not percentage points) and extend social transfers by US\$10 per capita. The cost of these interventions is US\$900 million and US\$850 million respectively. Finally, the stimulus is assumed to eliminate about a quarter of the productivity growth losses incurred during the financial crisis. The overall stimulus package simulated in the DCGE model costs US\$3.5 billion or 5 per cent of GDP in 2008. The 'stimulus' simulation captures key elements of the proposed 2009 stimulus package and is of similar magnitude.

\subsection{Impact of the 2008 food and fuel price crisis}

Table 6 presents the results for the food/fuel scenario, which captures the changes in commodity prices during 2008. Although price changes are modeled on a semester basis (i.e., half yearly), the table reports total impacts for 2008. As such, since the ban on additional rice exports was only imposed during the first half of 2008, the table reflects post-ban outcomes when world price changes had been transmitted to the domestic economy. As indicated earlier, Vietnam's terms of trade improved in 2008, because weighted export prices rose by more than import prices. This was primarily due to rice and crude oil, which are major export commodities whose prices rose significantly (see Table 5). Recall that the export ban applied only to incremental exports of rice. Existing rice exports benefited from higher prices even when the ban was in place. In addition, the ban was not in place in the second half of 2008 . The improvement in the terms of trade generates an appreciation of the real exchange rate, reflected in a reduced price of tradeable to non-tradeable commodities. The Vietnamese economy responds by reducing total exports, which fall by 1 per cent in volume terms below the baseline. Even though world import prices are rising, this is more than offset by the real appreciation and there is a slight increase in import volumes.

The rapid onset of the 2008 commodity crisis constrained producers' ability to respond to new external market conditions. This is captured in the model by fixing capital stock and land allocations and limiting labour substitution possibilities. There is still, however, a shift in resources towards commodities whose export profitability rises the most. Crop production, for example, expands by an additional 1.9 per cent as rice farmers eventually take advantage of higher export prices. This increases rural employment, mainly for lower-skilled farm workers. Conversely, manufacturing and services production falls, because the large real appreciation reduces their export competitiveness. Urban employment also declines as a result. Overall, the shift out of non-agriculture into lower productivity crop production causes

\footnotetext{
5 This is modeled as an increase in $b$ in eq.[8] in Table 5.

6 This implies a spending-to-productivity-growth elasticity of 0.05 since natural resource value-added is half of agricultural GDP and 5 percent of the state budget is allocated to agriculture (i.e., $0.03 / 0.05 / 0.5 \times 0.05=$ 0.06). This elasticity is below the econometrically estimated returns to irrigation (0.11), rural roads (0.07) and agricultural research and extension (0.06) (Fan et al. 2004) but reflects possible delays in the returns to investments.
} 
real GDP to decline slightly by 0.2 per cent. These results are consistent with the observed rise in agricultural GDP and decline in the growth of services GDP during 2008.

Table 6: Model results for the 2008 food and fuel crisis

\begin{tabular}{|c|c|c|c|}
\hline & \multicolumn{2}{|c|}{ Baseline scenario } & \multirow{2}{*}{$\begin{array}{c}\text { Food/fuel (1) } \\
\text { Deviation from } \\
\text { baseline, } 2008 \\
\text { (\% point) }\end{array}$} \\
\hline & Initial, 2007 & Change, $2008(\%)$ & \\
\hline Real GDP & 100.0 & 7.0 & -0.2 \\
\hline Absorption $(C+I+G)$ & 113.3 & 7.3 & 1.1 \\
\hline Consumption (C) & 57.6 & 5.3 & 1.5 \\
\hline Investment (I) & 41.6 & 9.9 & 0.8 \\
\hline Government (G) & 14.1 & 8.2 & 0.0 \\
\hline Exports (E) & 76.5 & 7.3 & -1.0 \\
\hline Imports (M) & 89.8 & 7.7 & 0.7 \\
\hline Real exchange rate & 100.0 & 1.5 & -2.1 \\
\hline Terms of trade & 100.0 & 0.0 & 2.3 \\
\hline Exports & 100.0 & 0.0 & 7.7 \\
\hline Imports & 100.0 & 0.0 & 5.3 \\
\hline Consumer price index & 100.0 & 0.5 & -1.4 \\
\hline GDP at factor cost & 100.0 & 7.0 & -0.2 \\
\hline Agriculture & 22.1 & 3.5 & 0.5 \\
\hline Crops & 13.4 & 3.4 & 1.9 \\
\hline Livestock & 2.7 & 4.5 & -0.2 \\
\hline Other & 5.9 & 3.0 & -2.2 \\
\hline Industry & 41.7 & 8.1 & -0.2 \\
\hline Mining & 10.9 & 6.2 & 0.5 \\
\hline Manufacturing & 20.1 & 8.1 & -1.0 \\
\hline Other & 10.7 & 10.2 & 0.7 \\
\hline Services & 36.2 & 8.0 & -0.6 \\
\hline Employment (mil.) & 39.1 & 2.7 & 0.9 \\
\hline Urban & 11.2 & 4.0 & -0.3 \\
\hline Rural & 27.9 & 2.3 & 1.4 \\
\hline National poverty (\%) & 47.3 & -1.4 & -3.6 \\
\hline Urban & 15.2 & -1.8 & 0.2 \\
\hline Rural & 59.0 & -1.2 & -5.0 \\
\hline
\end{tabular}

Notes: The first column of numbers provides, from the top, baseline shares of GDP, initial price index levels, baseline shares of GDP at factor, employment in millions, and the poverty rate. The poverty rate is based on a US\$2-per-day poverty line calculated using 2006 VHLSS (GSO 2007).

Source: Results from the Vietnam DCGE and microsimulation model.

Although economic growth declines slightly, there is still an increase in total absorption due to the terms of trade improvement. However, not all components of absorption are affected equally. Since recurrent government spending is constant in the model, tax revenues from oil exports are used to expand public investment. Overall, total investment demand rises by 0.8 per cent relative to the baseline. The increase in investment also benefits from cheaper imported machinery and accounts for the expansion of construction (included in 'other 
industry'). Falling consumer prices, caused by cheaper imported goods and higher food production, also causes real private consumption to expand by 1.5 per cent. Since absorption is an aggregate measure of welfare in the economy, the results suggest that the global commodity crisis had a positive effect on welfare in Vietnam.

The net employment-effects of the 2008 commodity crisis were also positive. At the nationallevel, employment increased by 0.9 per cent or about 350,000 jobs. Most of these new jobs are created in the agricultural sector, which explains why the rural poverty headcount declines by five percentage points. ${ }^{7}$ Overall, the commodity crisis reduced the number of people in Vietnam living below the US\$2-a-day poverty line by 3.1 million people. As shown in Figure 4, the poverty reduction only occurs after the lifting of the rice export ban. This is because the ban limited the increase in producer prices and hence many of the gains for rural farmers. Lifting of the ban during the second half of 2008 allowed domestic prices to adjust to higher world prices and for rural farmers to increase rice production, causing poverty to decline. Overall, this is a substantial decline in national poverty beyond what would have been expected without the positive terms of trade effects caused by the global commodity crisis.

Figure 4: National poverty headcount, 2007-10

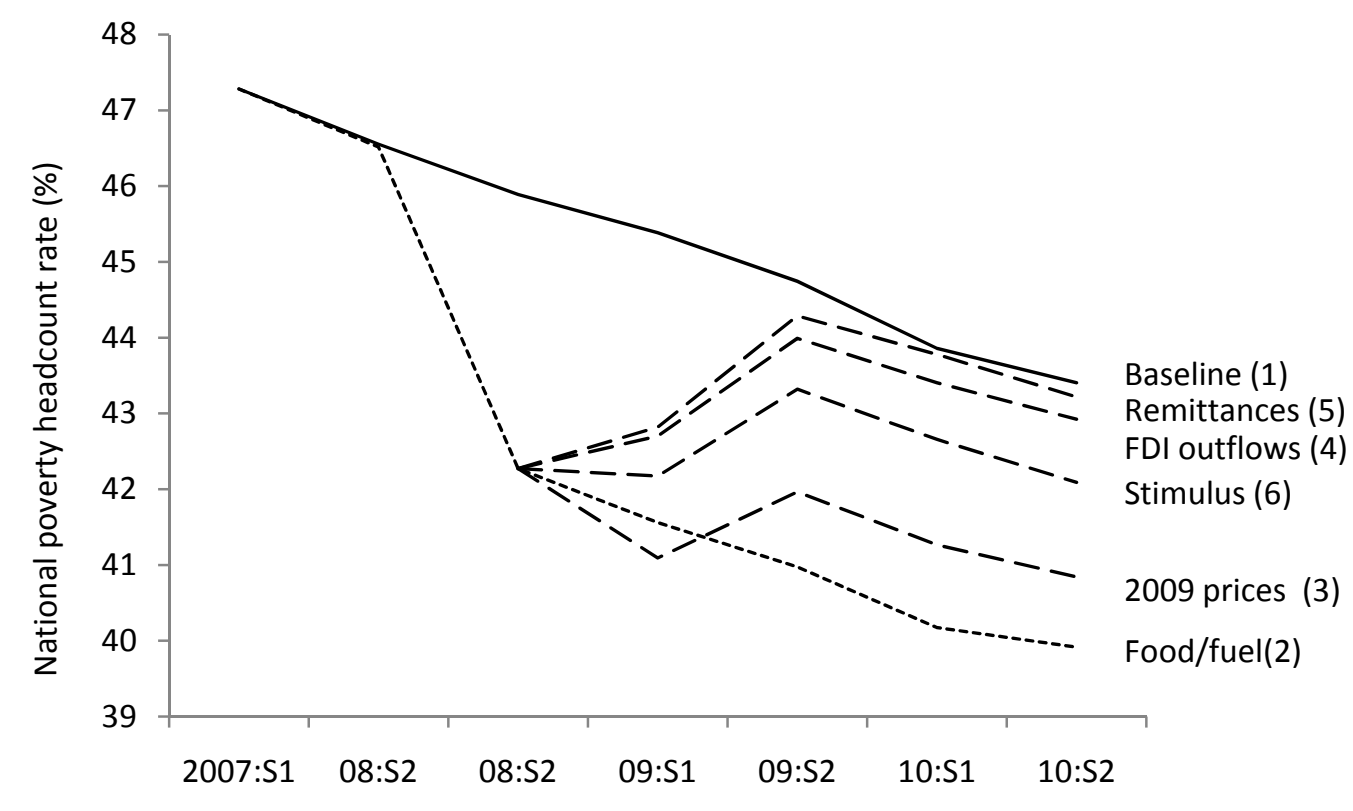

Note: Poverty rate is the US\$2-a-day poverty line calculated using 2006 VHLSS (GSO 2007).

Source: Results from the Vietnam DCGE and microsimulation model.

\subsection{The 2009 financial crisis and global recession}

Table 7 shows how the impact of the financial crisis is decomposed into falling world prices, FDI and remittances. Productivity growth is also reduced in order to track GDP and trade impacts. As indicated, simulations of the financial crisis are cumulative such that the remittances column reflects the full impact of the crisis in 2009 without any mitigating government stimulus and the final column indicates the effect assuming that the proposed

7 The poverty headcount rate is the share of the population living below the US\$2-a-day poverty line. 
stimulus package is fully enacted. The first two columns of results, labeled food/fuel scenario, show annual growth rates for 2009 assuming the high world prices prevailing in 2008 had continued into 2009. The remaining columns present contemporaneous percentage point differences from this food/fuel crisis scenario.

Table 7: Model results for the 2009 financial crisis

\begin{tabular}{|c|c|c|c|c|c|c|}
\hline & \multicolumn{2}{|c|}{ Food/fuel scenario (2) } & \multirow{2}{*}{$\begin{array}{c}2009 \\
\text { prices } \\
(3)\end{array}$} & \multirow{2}{*}{$\begin{array}{c}\text { FDI } \\
\text { outflows } \\
(4)\end{array}$} & \multirow{2}{*}{$\begin{array}{c}\text { Remit- } \\
\text { tances } \\
(5)\end{array}$} & \multirow{2}{*}{$\begin{array}{c}\text { Stimulus } \\
(6)\end{array}$} \\
\hline & \multirow{2}{*}{$\begin{array}{c}\text { Initial, } \\
2008 \\
\end{array}$} & \multirow{2}{*}{$\begin{array}{l}\text { Change, } \\
2009(\%)\end{array}$} & & & & \\
\hline & & & \multicolumn{4}{|c|}{ Deviation from food/fuel scenario, 2009 (\% point) } \\
\hline Real GDP & 100.0 & 7.2 & 0.5 & -3.4 & -3.7 & -2.3 \\
\hline Absorption $(\mathrm{C}+\mathrm{I}+\mathrm{G})$ & 115.0 & 7.6 & 1.5 & -4.1 & -5.3 & -2.2 \\
\hline Consumption (C) & 57.6 & 5.2 & 0.9 & -2.7 & -4.3 & -1.8 \\
\hline Investment (I) & 43.1 & 10.6 & 2.9 & -7.5 & -8.4 & -4.7 \\
\hline Government (G) & 14.3 & 8.2 & 0.0 & 0.0 & 0.0 & 3.9 \\
\hline Exports (E) & 76.2 & 7.7 & -0.6 & -4.5 & -4.1 & -4.4 \\
\hline Imports (M) & 91.1 & 8.1 & 0.9 & -5.3 & -6.0 & -3.9 \\
\hline Real exchange rate & 100.0 & 1.8 & -1.4 & -1.2 & -0.6 & -2.0 \\
\hline Terms of trade & 100.0 & 0.0 & 0.5 & 0.5 & 0.5 & 0.5 \\
\hline Exports & 100.0 & 0.0 & -6.8 & -6.8 & -6.8 & -6.8 \\
\hline Imports & 100.0 & 0.0 & -7.3 & -7.3 & -7.3 & -7.3 \\
\hline Consumer price index & 100.0 & 0.9 & 0.5 & 0.9 & 1.0 & 0.5 \\
\hline GDP at factor cost & 100.0 & 7.3 & 0.4 & -3.4 & -3.6 & -2.2 \\
\hline Agriculture & 21.5 & 3.2 & -0.1 & -1.6 & -1.8 & 0.3 \\
\hline Crops & 13.2 & 3.3 & -0.6 & -1.8 & -1.9 & 0.6 \\
\hline Livestock & 2.7 & 4.6 & 0.5 & -1.8 & -2.6 & -0.6 \\
\hline Other & 5.6 & 2.3 & 0.6 & -1.3 & -1.3 & 0.1 \\
\hline Industry & 42.1 & 8.4 & 0.4 & -4.6 & -4.9 & -3.9 \\
\hline Mining & 10.9 & 6.2 & -0.8 & -1.0 & -1.0 & -1.1 \\
\hline Manufacturing & 20.1 & 8.4 & 0.0 & -5.2 & -5.4 & -4.9 \\
\hline Other & 11.1 & 10.6 & 2.2 & -7.2 & -8.0 & -4.8 \\
\hline Services & 36.4 & 8.3 & 0.7 & -2.9 & -3.2 & -1.8 \\
\hline Employment (mil.) & 40.5 & 2.7 & -0.1 & -1.0 & -1.1 & -0.3 \\
\hline Urban & 11.6 & 3.9 & 0.6 & -0.2 & -0.3 & 0.2 \\
\hline Rural & 28.9 & 2.2 & -0.3 & -1.3 & -1.4 & -0.6 \\
\hline National poverty (\%) & 42.3 & -1.3 & 1.0 & 3.0 & 3.3 & 2.3 \\
\hline Urban & 13.6 & -0.7 & -0.6 & 0.5 & 0.5 & 0.0 \\
\hline Rural & 52.7 & -1.5 & 1.6 & 3.9 & 4.3 & 3.2 \\
\hline
\end{tabular}

Notes: The first column of numbers is similar to the first column of Table 6 but is based on simulation results from the food and fuel crisis scenario in 2008. From the top, the column contains shares of GDP, reinitialized price index levels, shares of GDP at factor, employment in millions, and the poverty rate. The poverty rate is based on a US\$2-per-day poverty line calculated using 2006 VHLSS (GSO 2007).

Source: Results from the Vietnam DCGE and microsimulation model.

We first focus on changes in world prices (see the third column of Table 7). Falling world prices in 2009 improved Vietnam's terms of trade even beyond the levels achieved in 2008. Based on 2007 trade shares, trade-weighted import prices fell faster than export prices. Note that import prices receive a larger weight in the terms of trade calculation due to Vietnam's trade deficit. The decline in the import price index is driven principally by falling prices for imported intermediates, such as metals, fuels, and textiles. The falling prices for imported investment goods, such as machinery and transport equipment, also reduces the import price index. Relative to the world prices prevailing under the food and fuel crisis, prices under the financial crisis improve terms of trade by 0.5 per cent. This causes the real exchange rate to appreciate by a further -1.4 per cent. Together, lower prices for major exports and the real appreciation cause real exports to fall by 0.6 per cent relative to the level registered in the food/fuel scenario in 2009. The real appreciation also favours imports, whose volume 
expands by 0.9 per cent. Changes in sector production are opposite to those experienced during the 2008 commodity crisis. Crop production falls alongside world rice prices. Urban employment increases while rural employment declines. In terms of the components of absorption, the high import intensity of investment permits real investment to rise due to lower world prices for imported investment goods combined with the real appreciation. Consumers also benefit from the improved terms of trade in the aggregate; but declining agricultural GDP reduces farm incomes for poorer rural households, with poverty rising as a result.

The impact of the financial crisis is both negative and more pronounced in the FDI and Remittances scenarios (see columns labeled (4) and (5) in Table 7). As expected, falling FDI causes a substantial contraction in total investment. The reduced demand for imported capital goods helps maintain external balance without a large depreciation of the real exchange rate. At the same time, reduced FDI implies a reduction in the growth rate of the capital stock. Since the model is run on a semester basis, the reduction in FDI in the first half of 2009 leads to reduced capital in the second half of 2009. Overall, by end 2009, real GDP declines due to reduced capital availability, lower levels of labour employment, and declines in factorspecific productivity growth of 0.5 and 1.5 percentage points for rural and urban factors respectively. This decline in economic activity causes household incomes and real consumption spending to fall. The results for the Remittances scenario indicate that half of the overall decline in consumption spending during the financial crisis was due to falling remittances, which directly affects households' incomes. Declining remittance inflows also reduces the real appreciation.

The largest reduction in economic growth following the crisis was in manufacturing and other industry. This is consistent with the declines in prices, demand, and foreign direct investment actually observed. The largest declines in production were for textiles and clothing. Machinery and construction (i.e., 'other industry') also contracted sharply because of lower investment demand, which uses these commodities intensively. FDI accounts for about a tenth and a third of total investment in agriculture and agro-processing respectively, and so these sectors contracted in the FDI outflows scenario. Declining world prices and weaker consumer demand also contributed to the decline of agriculture during the financial crisis. These results are consistent with the observed declines in sector GDP in 2009.

The financial crisis caused employment to fall by 1.1 per cent relative to the employment levels obtained in following the food and fuel crisis. More than 90 per cent of the 430,000 job losses were in rural areas, which is where most of the workforce is employed. However, urban employment also fell. The share of the population below the US\$2-a-day poverty line increased by 3.3 percentage points relative to the level attained in the food/fuel scenario in 2009. This is equivalent to an additional three million people living below the poverty as a result of the financial crisis. Furthermore, even though agriculture experienced the smallest relative contraction in output, rural poverty increases by more than in urban areas due to the declines, including job losses, in labour-intensive crop production. The bunching of rural households at consumption levels near the poverty line also implies a greater sensitivity of the poverty rate to consumption changes in rural versus urban areas.

\subsection{The 2009 government stimulus package}

Four components of the stimulus package are simulated, namely interest rate support to the private sector; public investments in agriculture; direct tax relief; and social transfers to 
households. 8 We assume that the government draws on foreign reserves in order to inject funds into the private sector. This lowers the decline in investment demand relative to the remittances scenario (see the final column in Table 7). Tax relief and social transfers also increase consumption spending, although it is insufficient to fully compensate for the decline in household incomes caused by the financial crisis. The increase in recurrent government spending reflects additional expenditure on agriculture. Together the increase in investment, consumption and recurrent spending offsets some of the decline in absorption caused by the financial crisis. The use of foreign exchange reserves drives a real appreciation in the currency relative to the remittances scenario thus encouraging imports and further reducing exports.

Agricultural GDP growth accelerates under the simulated stimulus package. This reduces the decline in rural employment. Increased investment generates immediate demand for construction (i.e., 'other industry'), which now declines at a slower rate. The overall decline industrial GDP caused by the financial crisis is also lessened by the stimulus package due to higher productivity levels, and despite the lag between providing interest rate support and the eventual translation of higher investment into new capital stocks. However, manufacturing relies on external demand, which is unaffected by the stimulus package. Thus, manufacturing growth remains largely unchanged. Rather, it is in the service sectors that the stimulus package generates additional urban employment. Lowering taxes and providing social transfers increases households' demand for consumer goods. Non-traded services, unlike industry, are less affected by import competition caused by the real appreciation. These results suggest that some of the resurgence in agriculture, construction and services during late 2009 can be attributed to the stimulus package.

Ultimately, the stimulus package prevents around two-fifths of the decline in total GDP caused by the financial crisis. The stimulus has a larger impacts on employment and causes a significant reduction in poverty. This is evident in Figure 4, which shows how the stimulus package lowers the increase in poverty caused by the financial crisis by about one third. This means that about 860,000 people are kept above the US\$2-a-day poverty line as a result of the simulated stimulus package. While this is still above the poverty levels that would have been achieved without the financial crisis, it is well below the baseline scenario which excludes the gains from the 2008 commodity crisis. However, the gap between between the food/fuel and stimulus scenarios in Figure 4 suggests that the increase poverty caused by the financial crisis will persist well into the future.

\section{Conclusion}

From a macroeconomic perspective, Vietnam has weathered the recent global crises relatively well. However, there is little rigorous analysis of why the effects were relatively small and not much quantitative evidence is available on how workers and households were affected, especially those at the lower end of the income distribution. In this paper, a dynamic economy-wide model was developed to decompose the effects of the crises and to translate the macro-level impacts of the crises into household incomes and poverty.

\footnotetext{
8 Note that our analysis does not consider the long-term implications of expanding the fiscal deficit and longterm debt position.
} 
Model results indicate that the 2008 commodity crisis improved Vietnam's terms of trade. It raised aggregate welfare and reduced poverty, mainly by expanding exports in labourintensive sectors. The 2009 financial crisis reversed the welfare gains from 2008. Even though world price shifts in 2009 improved Vietnamese terms of trade beyond the gains observed in 2008, reductions in demand for exports, FDI, and remittances caused a contraction in economic activity. The financial crisis pushed three million people below the US\$2-a-day poverty line relative to the food/fuel scenario. The vast majority of the population that fell into poverty resided in rural areas. Agriculture and the rural non-farm economy were limited in their ability to cushion the effects of the financial crisis. Vietnam's agricultural sector has a strong export-orientation, which makes it vulnerable to world market conditions.

The simulated impact of the government's stimulus package shows that it has the potential to offset some of the welfare losses caused by the financial crisis and substantially reduce the impact on poor households. Overall, the combined net effect of the two crises had little effect on poverty (and other principal macroeconomic indicators) compared with the baseline (no crises) path even assuming the stimulus policies designed to counter the financial crisis had no effect on current welfare. Under the assumption of an effective stimulus package, poverty rates are actually lower than the baseline (no crises) path.

\section{References}

Abbott, P., J. Bentzen, and F. Tarp (2009). 'Trade and Development: Lessons from Vietnam's Past Trade Agreements', World Development 37(2): 341-53.

Andersen, T.B., S. Jones, and F. Tarp (2008). 'The Current Financial Crisis: Implications and Issues for Less Developed Countries’, Briefing Paper, Department of Economics, University of Copenhagen.

Arndt, C., A. Garcia, H.H. Pham, and J. Thurlow (2009). 'A Provisional 2007 Social Accounting Matrix for Vietnam', unpublished manuscript, Department of Economics, University of Copenhagen, and Central Institute of Economic Management: Hanoi.

Dimaranan, B.V. (ed.) (2006). Global Trade, Assistance, and Production: The GTAP 6 Data Base, Center for Global Trade Analysis, Purdue University, Indiana.

Glewwe, P., M. Gragnolati, and H. Zaman (2002). 'Who Gained from Vietnam's Boom in the 1990s?', Economic Development and Cultural Change, 50: 773-92.

Fan, S., P.L. Huong, and T.Q. Long (2004). 'Government Spending and Poverty Reduction in Vietnam', report prepared for the World Bank by the International Food Policy Research Institute: Washington DC, and Central Institute of Economic Management: Hanoi.

GSO (2007). Results of the Survey of Household Living Standards 2006, General Statistical Office: Hanoi.

GSO (2009a). Statistical Yearbook of Vietnam 2008, General Statistical Office: Hanoi.

GSO (2009b). Monthly Statistical Information, General Statistical Office: Hanoi. Available at www.gso.gov.vn (last accessed 31 October 2009). 
Lofgren, H., S. Robinson, and M. El-Said (2002). A Standard Computable General Equilibrium (CGE) Model in GAMS, International Food Policy Research Institute: Washington DC.

Rapsomanikis, G., and A. Sarris (2007). 'The Impact of Domestic and International Commodity Price Volatility on Agricultural Income Instability in Ghana, Vietnam and Peru', in B. Guha-Khasnobis, S.A. Shabd, and B. Davis (eds) (2007) Food Security: Indicators, Measurement and the Impact of Trade Openness, Oxford University Press: Oxford.

Thurlow, J. (2004). 'A Dynamic Computable General Equilibrium (CGE) Model for South Africa: Extending the Static IFPRI Model', Trade and Industrial Policy Strategies Working Papers, No.1, Pretoria.

Van, L.T.T. (2009). 'Vietnam’s Policy Responses to the Financial Crisis', Background Brief, No. 447, East Asian Institute, National University of Singapore.

World Bank (2009a). World Development Indicators, World Bank: Washington DC.

World Bank (2009b). Commodity Price Data (Pink Sheets): October 2009, World Bank: Washington DC.

World Bank (2009c). 'Outlook for Remittance Flows 2009-2011: Remittances expected to fall by 7-10 percent in 2009', Migration and Development Brief, No.10, World Bank: Washington DC. 